\title{
Climatological Hydric Balance and the Trends Analysis Climatic in the Region of Machado in Minas Gerais State, Brazil
}

\author{
Gustavo Souza Rodrigues',2*, Fernando Ferrari Putti1,3, Antônio Carlos da Silva1, \\ Alisson Souza de Oliveira ${ }^{1}$, Luís Roberto Almeida Gabriel Filho ${ }^{3}$
}

${ }^{1} J o s e ́$ Rosário Vellano University (UNIFENAS), Alfenas, Brazil

${ }^{2}$ Machado Higher Education and Research Center (CESEP), Machado, Brazil

${ }^{3}$ Paulista State University Júlio de Mesquita Filho (UNESP), Botucatu, Brazil

Email: *prof.gustavo@outlook.com.br

How to cite this paper: Rodrigues, G.S., Putti, F.F., da Silva, A.C., de Oliveira, A.S. and Filho, L.R.A.G. (2018) Climatological Hydric Balance and the Trends Analysis Climatic in the Region of Machado in Minas Gerais State, Brazil. American Journal of Climate Change, 7, 558-574. https://doi.org/10.4236/ajcc.2018.74034

Received: July 30, 2018

Accepted: November 5, 2018

Published: November 8, 2018

Copyright ( 2018 by authors and Scientific Research Publishing Inc. This work is licensed under the Creative Commons Attribution International License (CC BY 4.0).

http://creativecommons.org/licenses/by/4.0/

Open Access

\begin{abstract}
Lately the planet's climate has been constantly changing, caused mainly by global warming which has exposed a great deal of concern to the population over the years. In order to understand the possible impacts that such changes may have on the environment and society in general, the importance of the analysis of climate and hydrological events trends and their performance in a region is justified. The objective of the present work was to perform the climatic classification and to evaluate the behavior of the Climatological Hydric Balance-CHB, from the region of Machado state of Minas Gerais-MG, taking into account a historical series of 55 years of climatic season data of the National Institute of Meteorology-INMET; to verify the occurrence of climatic changes by the temporal trends of precipitation and the average temperature, using the Mann-Kendall and Pettitt method; and the influence of these possible climate changes on CHB behavior and on the region's climate classification. Based on the results found it verified the increase in the water deficit between the months of June to September and a reduction in the water surplus from November to February. By means of the trend analysis, there was a positive trend of increase in the average temperature of $1.6^{\circ} \mathrm{C}$ until the year 2100 . The continuity and occurrence of these trends may have impacts on the economy, agriculture, the hydrological cycle, and consequently on the fauna, the flora and the population.
\end{abstract}

\section{Keywords}

Climatic Series, Global Warming, IPCC 


\section{Introduction}

The world's climate activity has been suffering severe changes, producing a raise in the number of environmental disasters and natural catastrophes, causing huge financial losses in many areas of the planet [1]. The studies and frequent discussions about natural resources and climate changes happen due to its importance to the existence of life on the planet, and, mainly, for its exaggerated and uncontrolled use [2].

The damage to the society, to the economy and to the environment caused by climate changes is frequently showed by the press and, among the most relevant economic activities, Cecílio et al. [3] and Pereira et al. [4] point out that the agribusiness sector is more dependent on the climate conditions. It happens because the climate conditions affect all of the phases of the productive chain, since the preparation of the soil for the seeding until the harvest, the transportation, the preparation, the products' storage and their commercialization.

In order to have an adequate planning of the tillage, the climate conditions and the soil from the different agricultural regions have to be considered. Thus, the good establishment of a crop in the tillage depends mainly on the water availability, on the soil technical features, on the amount of heat and solar energy. When a shortfall or excess of these elements occurs, it will possibly reduce the tillage's productivity.

According to Marin et al. [2], The Climate Hydric Balance-CHB is an important tool to study the clime of a certain region. In this sense, the $\mathrm{CHB}$, described by Thornthwaite and Mather (1955), is used to monitor the water storage's variation in soil-plant-atmosphere system.

The CHB can be calculated by the accounting of the natural supply of groundwater, rainfall $(\mathrm{P})$ and atmospheric demand, through the potential evapotranspiration (ETP), and with a maximum level of storage or available water capacity, appropriate to the present study. The $\mathrm{CHB}$ provides estimative of water deficiency (DEF), water surplus (EXC), real evapotranspiration (ETR) and storage of groundwater (ARM). The $\mathrm{CHB}$ can be elaborated in a daily scale, in specific days, or monthly or annual scale [4] [5] [6].

The Knowledge of the $\mathrm{CHB}$ elements guides the agricultural planning and management. Besides, it supports the climate and agro ecological zoning; the definition of the most appropriate times for the main processes in the crop, such as soil preparation, seeding and planting, pulverization and harvest; the estimation of the crops productivity; irrigation design and management; management of hydric resources in river basins; the selection and sizing of techniques for the conservation of water and soils [3] [7].

According to the IPCC report [1], it is clear that the earth's temperature is increasing and the projections to the end of this century point to raises from $1.1^{\circ} \mathrm{C}$ to $6.4^{\circ} \mathrm{C}$ in the average air temperature, in many places around the earth, including Brazil. It could bring considerable losses to agriculture and livestock activities and a new agroclimatic aptitude configuration to the many agricultural crops around the world. 
Studies aiming the detection of possible climate tendencies applied satisfactorily the Mann-Kendell method in climate variations. The World Meteorological Organization (OMM) suggests this test for tendency identification in time series [8] [9] [10]. In order to find if there was sudden change in the average of the series we can use the Pettitt test [11]. Two samples from the same time series that could be considered belonging to the same population were analyzed.

Salviano, Groppo e Pellegrino [8] analyses the time inclinations of the average temperature and precipitation in Brazil. They show that these tendencies are not significant regarding precipitation in a big part of the country. However, the average temperature showed a significant raising tendency in a big part of Brazil over the year. Queiroz [9] tried to evaluate this tendency in 46 historical series in the State of Minas Gerais using the Mann-Kendall test and other methodologies. He found an increasing tendency in many historical series.

In the same way, the study of the climate information daily collected is of great importance to study and predict the main severe hydric phenomena such as droughts, storms and hail rains. Those phenomena are essential to understand the climate changes and the possible impacts that they may cause in a certain area [1] [8] [9].

The objective of this work was to evaluate the behavior of BHC and to determine the existence of changes in the climate due to the temporal trends of precipitation and the average temperature in the Machado-MG region, investigating the influence of possible climatic changes on $\mathrm{BHC}$ behavior.

\section{Materials and Methods}

\subsection{Description of Study Area}

The studying area is represented by the city of Machado, located in the micro region of Alfenas in the south of the Minas Gerais state. It has a territorial area of approximately $586 \mathrm{~km}^{2}$ and is located in the geographic coordinates of latitude $21^{\circ} 40^{\prime} 30^{\prime \prime} \mathrm{S}$ and longitude $45^{\circ} 55^{\prime} 12^{\prime \prime} \mathrm{W}$. Its main economic activity is the agriculture exploitation and coffee is the main economic product and a massive generator of employment [12].

\subsection{Climate Data}

In order to use the statistic method determined for this research, a meteorological mean of 55 years of daily climate data was applied. The data is from to the climatological station of the INMET-National Institute of Meteorology located in Machado-MG.

The data obtained in INMET are related to the monthly and annual means of a historical series from 1961 to 2015, referring to temperature and precipitation. The organization and tabulation of the data were executed using an electronic speadsheet.

\subsection{Methodology of Hydric Balance and Climate Classification}

According to Marin et al. [2] the CHB can be determined through the local or 
sectional hydric availability information, the calculation of water deficit (DEF), the water excess (EXC) and the removal and recharging of groundwater.

In order to elaborate and estimate the $\mathrm{CHB}$ by Thornhwaite and Mather method [13] the balance between the inputs and outputs of water in the soil-plant system is made taking into account the storage capacity of soil water (CAD). The storage capacity of soil water (CAD) represents the maximum water availability that a certain kind of soil can retain depending on their physical characteristics.

To elaborate the CHB of this research, we used a model of an electronic spreadsheet developed by Rolim, Sentelhas and Barbieri [14]. When the CHB has only climatic purposes, the use of CAD in the soil being equivalent to 100 or $125 \mathrm{~mm}$ is recommended.

Firstly, monthly climatic potential evapotranspiration, in $\mathrm{mm}$, was estimated through the Thornthwaite and Mather [13] method, in which the uncorrected monthly evapotranspiration potential was calculated (considering 12 hour days and a 30 days month). Then, it was multiplied by the correction factor, which is a dependent on the latitude and on the months of the year.

$$
\mathrm{ETP}=16(10 t / I)^{a}
$$

ETP $=$ potential evapotranspiration for a 30 days month with a 12 hour insolation $(\mathrm{mm}), t$ is the average temperature of the month $\left({ }^{\circ} \mathrm{C}\right)$ and $a$ is the cubic function of $I$ (that can be calculated by the formula)

$$
a=6.75 \times 10^{-7} I^{3}-7.71 \times 10^{-5} I^{2}+1.792 \times 10^{-2} I+0.49239
$$

$I$ is the annual calorific value.

The value of $I$ can be calculated by summing the 12 values of the monthly calorific indices $(i)$, which can be calculated by the following formula:

$$
i=\left(t^{\prime} / 5\right)^{1,514}
$$

$t^{\prime}$ is the common monthly average temperature $\left({ }^{\circ} \mathrm{C}\right)$.

After estimating the evapotranspiration, the calculation of Thornthwaite and Mather [13] started. To do so, some calculation factors used in CHB are necessary:

P-ETP: Calculates the difference between precipitation $\mathrm{P}$ and the estimated potential evapotranspiration (ETP) in order to collect positives and negative balances. In most areas, the most common is the occurrence of a rainy season followed by a drought. In the humid months P-ETP are positives, indicating excessive rainfall, while in the dry months P-ETP is negative, representing potential water loss. When the situation is the water recharge in the soil, that is, whenever the (PETP) $\geq 0$, it has to be added to ARM (storage) of the previous period and through this new ARM, it is possible to calculate the new NAc (accumulated negative) by the following expression:

$$
\mathrm{NAc}=\mathrm{CAD}\left(\ln \frac{\mathrm{ARM}}{\mathrm{CAD}}\right)
$$

When there is withdrawal of the water in the soil, that is, when the (P-ETP) < 
0 , it has to be accumulated and through the (P-ETP) we calculate the ARM, using the following expression:

First, we calculate the Nac by the equation:

$$
\mathrm{NAc}=\mathrm{NAc}+\mathrm{NAc}_{\text {previous }}
$$

Then, we calculate the ARM:

$$
\operatorname{ARM}=\operatorname{CAD}\left(e^{-\left|\frac{\mathrm{NAc}}{\mathrm{CAD}}\right|}\right)
$$

ALT-Storage Alteration

$$
\mathrm{ALT}=\mathrm{ARM}-\mathrm{ARM}_{\text {anterior }}
$$

ALT $>0$ There was replacement

ALT $<0$ There was withdrawal of water from the soil

ETR-Real Evapotranspiration

If,

$$
\mathrm{ETR}=\mathrm{P}+|\mathrm{ALT}|
$$

If $(P-E T P) \geq 0$,

$$
\mathrm{ETR}=\mathrm{ETP}
$$

DEF-Hydric deficiency: refers to the amount that the soil-plant system did not evapotranspirate

$$
\mathrm{DEF}=\mathrm{ETP}-\mathrm{ETR}
$$

EXC-Water surplus: it is related to the water that the soil cannot retain or evapotranspirate

If $\mathrm{ARM}<\mathrm{CAD}$,

$$
\mathrm{EXC}=0
$$

If $\mathrm{ARM}=\mathrm{CAD}$,

$$
\mathrm{EXC}=(\mathrm{P}-\mathrm{ETP})-\mathrm{ALT}
$$

In order to do the climate classification by the Thornthwaite and Mather method [13], we use indices calculated based on the CHB. The hydric index $\left(I_{n}\right)$, the arid index $\left(I_{a}\right)$ and the humidity index $\left(I_{u}\right)$, connected to the hydric availability, are defined from the annual values. The climate types (Table 1) were defined based on the humidity index $\left(I_{u}\right)$, while the subtypes were defined by the arid index (Table 2).

$$
\begin{gathered}
I_{h}=(\mathrm{EXC} / \mathrm{ETP}) \times 100 \\
I_{a}=(\mathrm{DEF} / \mathrm{ETP}) \times 100 \\
I_{u}=I_{h}-\left(0.6 \times I_{a}\right)
\end{gathered}
$$

In order to classify the thermal factor (TE), the climate types are defined based on the annual potential evapotranspiration (annual ETP). The subtypes depend on the percentage relation between the potential evapotranspiration in the 
Table 1. Climate types, according to Thornthwaite, based on the humidity index $\left(I_{u}\right)$.

\begin{tabular}{cc}
\hline Climate types & Humidity index $\left(I_{u}\right)$ \\
\hline $\mathrm{A} \rightarrow$ super humid & $I_{u} \geq 100$ \\
$\mathrm{~B}_{4} \rightarrow$ humid & $80 \leq I_{u}<100$ \\
$\mathrm{~B}_{3} \rightarrow$ humid & $60 \leq I_{u}<80$ \\
$\mathrm{~B}_{2} \rightarrow$ humid $40 \leq I_{u}<60$ & $40 \leq I_{u}<60$ \\
$\mathrm{~B}_{1} \rightarrow$ humid $20 \leq I_{u}<40$ & $20 \leq I_{u}<40$ \\
$\mathrm{C}_{2} \rightarrow$ semi-humid $0 \leq I_{u}<20$ & $0 \leq I_{u}<20$ \\
$\mathrm{C}_{1} \rightarrow$ dry semi-humid $-20 \leq I_{u}<0$ & $-20 \leq I_{u}<0$ \\
$\mathrm{D} \rightarrow$ semi-arid $-40 \leq I_{u}<-20$ & $-40 \leq I_{u}<-20$ \\
$\mathrm{E} \rightarrow$ arid $-60 \leq I_{u}<-40$ & $-60 \leq I_{u}<-40$
\end{tabular}

Table 2. Climatic subtypes, according to Thornthwaite, based on the arid $\left(I_{a}\right)$ and hydric $\left(I_{h}\right)$ indexes.

\begin{tabular}{cc}
\hline Humid climes (A, B, C2) & Arid index $\left(I_{\mathrm{a}}\right)$ \\
\hline $\mathrm{r} \rightarrow$ without or with a small hydric deficit & $0 \leq I_{a}<16.7$ \\
$\mathrm{~s} \rightarrow$ moderate hydric deficit in the summer & $16.7 \leq I_{a}<33.3$ \\
$\mathrm{w} \rightarrow$ moderate hydric deficit in the winter & $16.7 \leq I_{a}<33.3$ \\
$\mathrm{~s}_{2} \rightarrow$ big hydric deficit in the summer & $I_{a} \geq 33.3$ \\
$\mathrm{w}_{2} \rightarrow$ big hydric deficit in the winter & $I_{a} \geq 33.3$ \\
\hline Dry climes (C1, D, E) & Arid index $\left(I_{\mathrm{a}}\right)$ \\
\hline $\mathrm{d} \rightarrow$ small or null water surplus & $0 \leq I_{h}<10$ \\
$\mathrm{~s} \rightarrow$ moderate water surplus in the summer & $10 \leq I_{h}<20$ \\
$\mathrm{w} \rightarrow$ moderate water surplus in the winter & $10 \leq I_{h}<20$ \\
$\mathrm{~s}_{2} \rightarrow$ big water surplus in the summer & $I_{h} \geq 33.3$ \\
$\mathrm{w}_{2} \rightarrow$ big water surplus in the winter & $I_{h} \geq 33.3$ \\
\hline
\end{tabular}

summer and the annual potential evapotranspiration (Table 3). ETP was used because it depends directly on the temperature [13].

$$
\begin{gathered}
\mathrm{TE}=\mathrm{ETP}_{\text {anual }} \\
\mathrm{TE}=\left(\mathrm{ETP}_{\text {noverão }} / \mathrm{ETP}_{\text {anual }}\right) \times 100
\end{gathered}
$$

\subsection{Methodology of Tendency Analysis-Mann-Kendall and Pettitt Test}

The non-parametric tendency test of Mann-kendall-MK [15] [16], consists of comparing each value of the time series with the rest of the values, always in a sequential order, counting the number of the times that the rest of the terms are higher than the analyzed value. The method describes the tendency of a time data series. It is appropriated when the case could be assumed as monotonic, therefore, they do not present any seasonal cycle or another tendency in the data 
Table 3. Climatic types and subtypes according to Thornthwaite, basead on the thermal index.

\begin{tabular}{cccc}
\hline \multicolumn{1}{c}{ Climate types } & ETP annual $(\mathrm{mm})$ & $\begin{array}{c}\text { Climate } \\
\text { Subtypes }\end{array}$ & $\begin{array}{c}\text { (ETP in the summer /ETP annual) } \\
* 100\end{array}$ \\
\hline $\mathrm{A}^{\prime} \rightarrow$ megathermic & ETP $\geq 1140$ & $\mathrm{a}^{\prime}$ & Less than $48.0 \%$ \\
$\mathrm{~B}_{4}^{\prime} \rightarrow$ mesothermic & $1140>\mathrm{ETP} \geq 997$ & $\mathrm{~b}_{4}^{\prime}$ & between $48.0 \%$ and less than $51.9 \%$ \\
$\mathrm{~B}_{3}^{\prime} \rightarrow$ mesothermal & $997>\mathrm{ETP} \geq 885$ & $\mathrm{~b}_{3}^{\prime}$ & between $51.9 \%$ and less than $56.3 \%$ \\
$\mathrm{~B}_{2}^{\prime} \rightarrow$ mesothermal & $885>\mathrm{ETP} \geq 712$ & $\mathrm{~b}_{2}^{\prime}$ & between $56.3 \%$ and less than $61.6 \%$ \\
$\mathrm{~B}_{1}^{\prime} \rightarrow$ mesothermal & $712>\mathrm{ETP} \geq 570$ & $\mathrm{~b}_{1}^{\prime}$ & between $61.6 \%$ and less than $68.0 \%$ \\
$\mathrm{C}_{2}^{\prime} \rightarrow$ microthermal & $570>\mathrm{ETP} \geq 427$ & $\mathrm{c}_{2}^{\prime}$ & between $68.0 \%$ and less than $76.3 \%$ \\
$\mathrm{C}_{1}^{\prime} \rightarrow$ microthermal & $427>\mathrm{ETP} \geq 287$ & $\mathrm{c}_{1}^{\prime}$ & between $76.3 \%$ and less than $88.0 \%$ \\
$\mathrm{D}^{\prime} \rightarrow$ tundra & $287>\mathrm{ETP} \geq 142$ & $\mathrm{~d}^{\prime}$ & equal or more than $88.0 \%$ \\
$\mathrm{E}^{\prime} \rightarrow$ perpetual ice & ETP $<142$ & & \\
\hline
\end{tabular}

[17]. The MK method is the most appropriate to analyze climate changes in climatological series. It is suggest by the World Meteorological Organization (OMM) to identify tendencies in time series [18].

In MK test, the $\mathrm{S}$ statistic is calculated by the summing of all counts, as follows:

$$
S=\sum_{i=1}^{n-1} \sum_{j=i+1}^{n} \operatorname{sgn}\left(x_{j}-x_{i}\right)
$$

In which,

$$
\operatorname{sgn}\left(x_{j}-x_{i}\right)= \begin{cases}+1 ; & \text { if } x_{j} \geq x_{i} \\ 0 ; & \text { if } x_{j}=x_{i} \\ -1 ; & \text { if } x_{j}<x_{i}\end{cases}
$$

The $S$ statistic tends to normality for a large $n$, with mean and variance given by:

$$
\begin{aligned}
& E\left[S_{i}\right]=0 \\
& \operatorname{Var}(s)=\frac{n(n-1)(2 n+5)-\sum_{j=1}^{p} t_{j}\left(t_{j}-1\right)\left(2 t_{j}+5\right)}{18}
\end{aligned}
$$

In which $n$ is the size of the time series. Therefore, the statistic test $Z$ is given by:

$$
Z= \begin{cases}\frac{S-1}{(\operatorname{Var}(S))^{\frac{1}{2}}} & \text { se } S>0 \\ 0 & \text { se } S=0 \\ \frac{S+1}{(\operatorname{Var}(S))^{\frac{1}{2}}} & \text { se } S<0\end{cases}
$$

The considerable statistic tendency in the temporal series is measured by the $\mathrm{Z}$ value. This statistic is used to test the null hypothesis that the tendency does not 
exist. In Mann-Kendall test, a tendency is considered positive or negative, indicating a decrease or increase in the elements of the analyzed series, the case of Kandall's Tau is negative or positive. The statistical significance was analyzed by the $\mathrm{p}$-value test. The null hypothesis is not reject if $p$ value is more or equal $a$; if $p$ is less than $a$, the null hypothesis is rejected [15] [16].

In addition to the MK test, I did the Pettitt non parametric statistic test in order to evaluate the occurrence of abrupt changes in the means of the historical series. According to Pettitt [11], this test indicates if two samples from the same temporal series can be considered belonging to the same population.

The Petit test verifies two samples, $X_{1}, X_{2}, \cdots, X_{t}$ e $X_{t+1}, X_{t+2}, \cdots, X_{T}$ belonging to the same population, providing also information about the data homogeneity from the historical series analyzed. This statistic finds the point where an abrupt change in a temporal series occurred [11].

The $U_{t, T}$ statistic counts the times that a member of the first sample is higher than a member of the second sample. It can be written as:

$$
U_{t, T}=U_{t-1, T}+\sum_{j=1}^{T} \operatorname{sgn}\left(X_{i}-X_{j}\right)
$$

for $t=2, \cdots, T$

where: $\operatorname{sgn}(x)=1$ para $x>0$; $\operatorname{sgn}(x)=0$ for $x=0$; $\operatorname{sgn}(x)=-1$ for $x<0$.

The $U_{t, T}$ statistic is calculated for the $1<t<T$ values and the $K(t)$ statistic from Pettitt test is the maximum absolute value for $U_{t, T}$ This statistic locates the changing point of a temporal series and its meaning. It can be described as:

$$
\begin{gathered}
k(t)=M A X_{1 \leq t \leq T}\left|U_{t, T}\right| \\
p \cong 2 \exp \left\{-6 k(t)^{2} / T^{3}+T^{2}\right\}
\end{gathered}
$$

The abrupt changing point is the time $(t)$ where there is the maximum $k(t)$. We can calculate the critical $K$ values by the equation:

$$
\text { Kcrit }= \pm \sqrt{\frac{-\ln (p / 2)\left(T^{3}+T^{2}\right)}{6}}
$$

The significance level used was $5 \%$.

The software extension XLSTAT 2014.5.03, for Microsoft Office Excel, was used in order to analyse and organize the data.

\section{Results and Discussion}

\subsection{Climatological Hydric Balance and Climate Classification}

From of the graphs of surplus and water deficit we can precisely establish the driest periods, the rainy seasons, the traffic conditions for supplies and machines, the best seasons for the development of vegetation and for the beginning of a recovery process from degraded areas through the hydric surplus and deficiency graphics. The CHB analysis shows that, in the region of Machado, the dry season, when the highest hydric deficits are observed, maintains close values for the dif- 
ferent periods analyzed: a) Period (1961-1979), b) Period (1979-1998); c) Period (1998-2015); d) Period (1961-2015), varying between 9 to $16 \mathrm{~mm}$ in August, the most critical period regarding hydric deficiency (Table 4).

According to Matielo et al. [19], these climate conditions are favorable to the development of the coffee-growing in the region of Machado. According to Monteiro et al. [20], the climate characteristics of the region also favor the cultivation of other species, such as corn, beans and vegetables in general

The CHB shows a reduction in the hydric surplus for the specific a) Period (1961-1979), b) Period (1979-1998); c) Period (1998-2015); d) Period (1961-2015), mainly in February, October and November In August, the hydric deficit was more accentuated (Figure 1). The most critical reduction in the water surplus occurs in the month of November, which reduces the volume from $107.6 \mathrm{~mm}$ to $11.4 \mathrm{~mm}$.

According to Cunha and Martins [21], the climatic classification of Botucatu and São Manuel municipalities using the Köppen and Thornthwaite methodologies in air temperature and rainfall data over a period of 36 years (1971 to 2006) reinforces that both classifications showed similarities in the characterization of the climate, however, Köppen's climatic classification loses in detail, since it does not differentiate climatic types, whereas Thornthwaite, besides taking into account temperature, precipitation and evapotranspiration, presents in detail the period of deficit and annual water surplus of a locality.

I calculated the index to do the climate classification through the information obtained in the CHB. The hydric index was $\left(\mathrm{I}_{\mathrm{h}}=66.65\right)$, the aridity index was $\left(I_{a}=1.72\right)$, and the humidity index was $\left(I_{u}=65.62\right)$. Regarding the thermal factor (TE), the climate types were defined by the potential annual evapotranspiration $\left(\mathrm{ETP}_{\text {anual }}=930.77 \mathrm{~mm}\right)$ and by the percentual relation between the potential evapotranspiration in the summer and the potential annual evapotranspiration $(($ ETP in the summer/ETP annual $) \times 100=33.60 \%)$.

Thus, the climate classification of the region of Machado is a humid mesothermic clime, with little hydric deficit $\left(\begin{array}{lll}\mathrm{B}_{3} \mathrm{r} & \mathrm{B}_{3}^{\prime} & a^{\prime}\end{array}\right)$.

\subsection{Analysis of Climate Change Tendencies}

Craparo et al. [22] and Assad et al. [23] approaches climate changes and global warming as the beginning of a new geological configuration in the seeding and coffee-growing (Coffea arabica) in Brazil, bringing possible economic losses. In a pessimistic scenario, about $33 \%$ of the current coffee-growing areas can became unable or of climate high risks. The MAPA [24] shows that events such as hydric stress caused by the droughts, rain excess, low or high temperatures can bring serious damages to the agricultural and livestock activities.

\subsubsection{Precipitation}

According to the climatic data from region of Machado-MG, there is only a significant reduction tendency in October, with a rate of $1.7 \mathrm{~mm}$ per year, which is significant for two tests (Table 5). 
Table 4. Mean monthly values of the volume $(\mathrm{mm})$ of water deficiency and water surplus in the different periods analyzed for the region of Machado-MG.

\begin{tabular}{ccccccccc}
\hline & \multicolumn{7}{c}{ PERIOD ANALYZED IN CHB } \\
\cline { 2 - 8 } MONTH & \multicolumn{1}{c}{$1961-1979$} & $1979-1998$ & \multicolumn{2}{c}{$1998-2015$} & \multicolumn{1}{c}{$1961-2015$} \\
\cline { 2 - 9 } & DEF & EXC & DEF & EXC & DEF & EXC & DEF & EXC \\
\hline JANUARY & 0.0 & 159.0 & 0.0 & 182.6 & 0.0 & 181.0 & 0.0 & 179.7 \\
FEBRUARY & 0.0 & 111.5 & 0.0 & 109.1 & 0.0 & 104.4 & 0.0 & 109.0 \\
MARCH & 0.0 & 63.8 & 0.0 & 117.6 & 0.0 & 70.3 & 0.0 & 84.2 \\
APRIL & -0.1 & 0.0 & 0.0 & 6.5 & -0.3 & 0.0 & 0.0 & 0.0 \\
MAY & -0.1 & 0.0 & 0.0 & 11.3 & -0.3 & 0.0 & 0.0 & 0.0 \\
JUNE & -1.6 & 0.0 & -0.7 & 0.0 & -3.6 & 0.0 & -1.1 & 0.0 \\
JULY & -1.8 & 0.0 & -3.8 & 0.0 & -6.9 & 0.0 & -3.3 & 0.0 \\
AUGUST & -8.0 & 0.0 & -14.3 & 0.0 & -16.7 & 0.0 & -11.6 & 0.0 \\
SEPTEMBER & -3.7 & 0.0 & 0.0 & 0.0 & -3.6 & 0.0 & 0.0 & 0.0 \\
OCTOBER & 0.0 & 20.4 & 0.0 & 20.1 & 0.0 & 0.0 & 0.0 & 0.0 \\
NOVEMBER & 0.0 & 107.6 & 0.0 & 81.8 & 0.0 & 11.4 & 0.0 & 82.3 \\
DECEMBER & 0.0 & 172.2 & 0.0 & 210.0 & 0.0 & 131.2 & 0.0 & 165.4 \\
\hline
\end{tabular}

Table 5. Statistic results from the Precipitation data for the Mann-Kendall and Pettitt Test for the region of Machado-MG.

\begin{tabular}{cccccc}
\hline \multirow{2}{*}{ MONTH } & \multicolumn{2}{c}{ MANN-KENDALL } & & PETTITT & \\
\cline { 2 - 6 } & $p$-valor & Kendall's Tau & $p$-valor & K & $\begin{array}{c}\text { Changing } \\
\text { point (t) }\end{array}$ \\
\hline JANUARY & 0.5594 & -0.0601 & 0.8418 & 102.0 & 8 \\
FEBRUARY & 0.7039 & -0.0390 & 0.9131 & 95.0 & 11 \\
MARCH & 0.6020 & 0.0532 & 0.6738 & 126.0 & 14 \\
APRIL & 0.8252 & 0.0230 & 0.6346 & 130.0 & 8 \\
MAY & 0.6778 & 0.0426 & 0.3918 & 159.0 & 21 \\
JUNE & 0.9929 & 0.0018 & 0.4385 & 154.0 & 22 \\
JULY & 0.7621 & 0.0313 & 0.9691 & 82.0 & 8 \\
AUGUST & 0.2122 & -0.1266 & 0.4439 & 152.0 & 16 \\
SEPTEMBER & 0.5574 & 0.0595 & 0.6073 & 133.0 & 21 \\
OCTOBER & 0.0059 & -0.2730 & 0.0261 & 265.0 & 31 \\
NOVEMBER & 0.7105 & -0.0541 & 0.7936 & 108.0 & 19 \\
DECEMBER & 0.6800 & 0.0598 & 0.1156 & 208.0 & 25 \\
\hline
\end{tabular}

Santos [25] analyzing the trends in precipitation indices in a 39-year historical series of a rainfall station located in Uberlândia-MG, concluded that although some historical series show positive trends, indicating an increase in rainfall volume, and other series negative tendencies, one can't be sure about the relevance 




(a) Period (1961-1979)

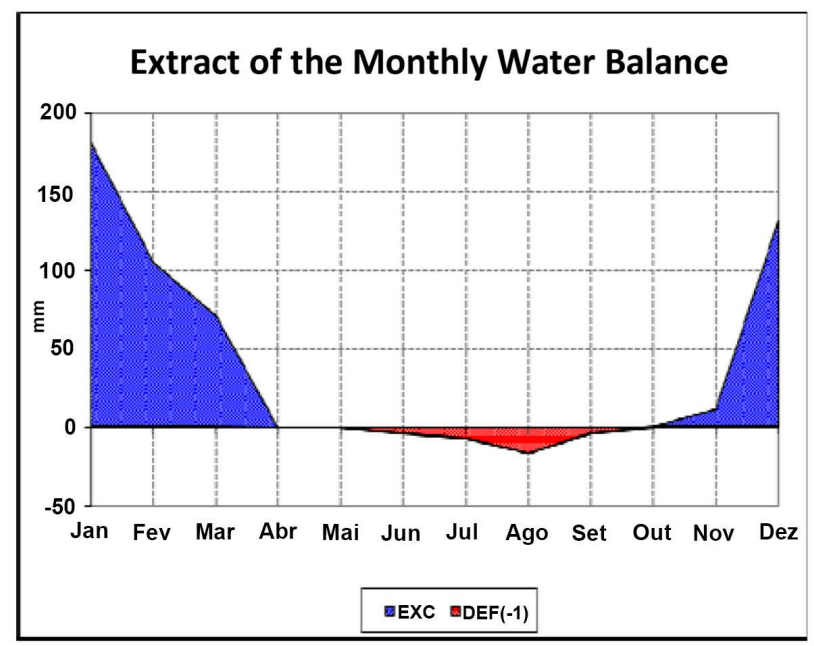

(c) Period (1998-2015)

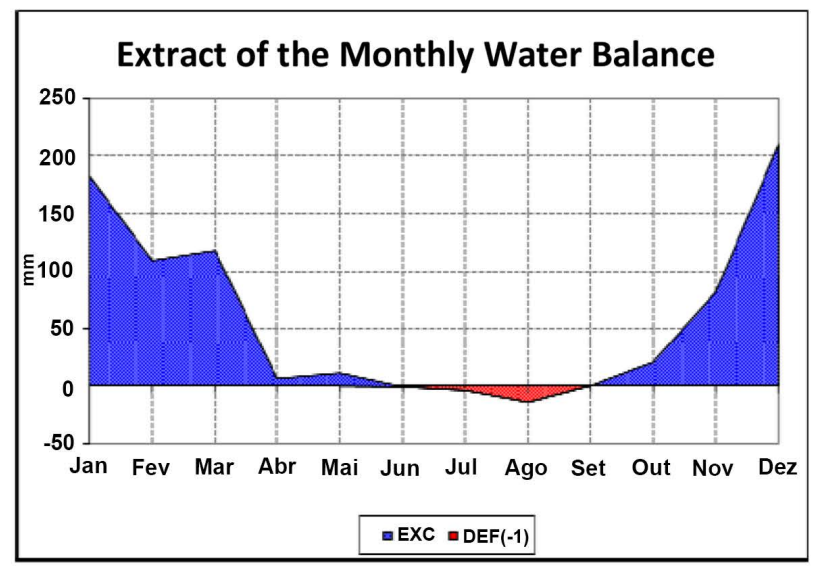

(b) Period (1979-1998)

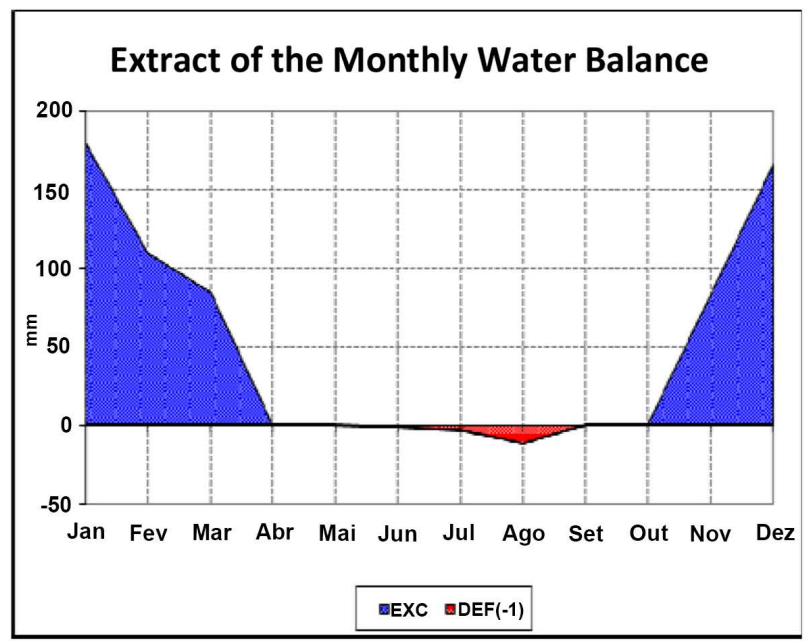

(d) Period (1961-2015)

Figure 1. Extract of the Climatological water balance in the Machado-MG region.

of this variation, stating that this fact may be reflections of natural fluctuations and random behaviors inherent to the historical series itself.

However, Salviano, Groppo and Pellegrino [8], in investigating the temporal trends of precipitation and average temperature in Brazil, verified that precipitation did not present significant trends in more than $70 \%$ of the Brazilian territory in every month.

\subsubsection{Temperature}

We can observe throught the climate data in Table 6 that there is a tendency of a raise in $0.019^{\circ} \mathrm{C}$ per year in January, confirmed by the two tests, considering that according to Pettitt test, the tendency tends to occur from the year of 1994 on. To February, the tendency is a $0.016^{\circ} \mathrm{C}$ raise per year, significative to Mann-Kendall and not significant for Pettitt. However, this test indicates that the tendency tends to occur at the same time as in January. April presents an increasing tendency of $0.021^{\circ} \mathrm{C}$ per year, significant for the two tests, happening from 1982 on. July presents an increasing tendency of $0.016^{\circ} \mathrm{C}$ per year, significant 
Table 6. Statistic results of the Temperature data for Mann-kendall and Pettitt tests for Machado-MG.

\begin{tabular}{cccccc}
\hline \multirow{2}{*}{ MONTH } & \multicolumn{2}{c}{ MANN-KENDALL } & \multicolumn{3}{c}{ PETTITT } \\
\cline { 2 - 6 } & $p$-valor & Kendall's Tau & $p$-valor & K & Changing point $(\mathrm{t})$ \\
\hline JANUARY & 0.0323 & 0.2241 & 0.0147 & 249.0 & 25 \\
FEBRUARY & 0.0363 & 0.2173 & 0.1532 & 183.0 & 25 \\
MARCH & 0.1113 & 0.1657 & 0.1795 & 178.0 & 26 \\
APRIL & 0.0007 & 0.3455 & 0.0007 & 320.0 & 19 \\
MAY & 0.1879 & 0.1374 & 0.1823 & 176.0 & 16 \\
JUNE & 0.3064 & 0.1071 & 0.5350 & 128.0 & 31 \\
JULY & 0.0248 & 0.2347 & 0.1293 & 186.0 & 14 \\
AUGUST & 0.4775 & 0.0747 & 0.6033 & 120.0 & 31 \\
SEPTEMBER & 0.1100 & 0.1682 & 0.0844 & 199.0 & 32 \\
OCTOBER & 0.0003 & 0.3700 & 0.0010 & 311.0 & 19 \\
NOVEMBER & 0.0350 & 0.2265 & 0.0590 & 195.0 & 15 \\
DECEMBER & 0.0178 & 0.2474 & 0.0036 & 248.0 & 20 \\
\hline
\end{tabular}

for Mann-kendall and not significant for Pettitt. However, the test indicates that the tendency started in 1976. October presents an increasing tendency of $0.029^{\circ} \mathrm{C}$ per year, significant for Mann-kendall and not significant for Pettitt. However, the test indicates that the tendency started in 1982 . November presents an increasing tendency of $0.0016^{\circ} \mathrm{C}$ per year, significant for Mann-kendall and not significant for Petit, considering that the tendency started in 1977. And for the month of December there is a trend of increase of $0.019^{\circ} \mathrm{C}$ per year, significant for both tests, and the trend occurs from 1985.

In accordance with to the IPCC report [1], it is clear that the planet's temperature is increasing, and projections until the end of this century point to increases between $1.1^{\circ} \mathrm{C}$ to $6.4^{\circ} \mathrm{C}$ in the average air temperature in many areas of the planet, including Brazil. It can bring enormous damages to the agricultural and livestock activities, besides a new configuration of the agro-climatic aptitude in many agricultural crops cultivated all around the world [26] [27] [28].

According to the National Supply Company-CONAB [29] the coffee harvest in South Minas must be around 10 million bags 5.09\% less than the estimative published in June and 5\% less than the last harvest. The last harvest was extremely damaged by the long drought and high temperatures and was of 10.8 million bags.

Avila et al. [30], when evaluating the trends of minimum and maximum temperatures in the State of Minas Gerais, using data from a historical series of 30 years of minimum and maximum air temperatures, from 43 municipalities, concluded that trends of increasing minimum temperatures and the highest in the month of October, for most of the municipalities of Minas Gerais. 
Salviano, Groppo and Pellegrino [8] analyzing the temporal trends of precipitation and average temperature in Brazil found that the average temperature showed a significant positive trend in most of Brazil throughout the year, thus reinforcing the results of this research.

By simulating the increase in temperature from the tendency data obtained, a considerable increase in temperature is observed for the next century. The results reinforce the data obtained by the IPCC surveys, with an average increase of $1.6^{\circ} \mathrm{C}$ (Table 7). This scenario is worrying for the coffee industry in the region because of the negative impacts that the average temperature increase brings to a given crop.

\subsection{Behavior of the Climatological Hydric Balance}

In Figure 2, the normal monthly $\mathrm{CHB}$ and the $\mathrm{CHB}$ extract, for the region of Machado-MG, respectively, can be visualized according to the climatological normal of the region from the data series used in this study. The dry season, when the highest values of water deficit are observed, in July, August and September, registered a total annual hydric $16 \mathrm{~mm}$ deficit and in the rainy season a $620.4 \mathrm{~mm}$ surplus.

In Figure 3, the normal monthly $\mathrm{CHB}$ and the $\mathrm{CHB}$ extract, respectively, can be visualized simulating the climate changes presented through the tendency tests. The dry season in July, August and September and April presented a deficit and had an accentuated increase in October. Thus, the annual hydric deficit was $71.5 \mathrm{~mm}$ and the excess in the rainy season was $488.4 \mathrm{~mm}$. The relationship between the tendencies in climate changes and the reduction of the volume of water in the hydric balance is evident (Table 8).

Table 7. Prediction of the rise in temperature until the years of 2011 for Machado-MG area.

\begin{tabular}{cccc}
\hline MONTH & REGRESSION MODEL & $\mathbf{R}^{2}$ & $\begin{array}{c}\text { TEMPERATURE INCREASE YEAR 2100 } \\
\left({ }^{\circ} \mathrm{C}\right)\end{array}$ \\
\hline JANUARY & $-15.59717+0.01917^{*}$ Ano & 0.1679 & 1.577 \\
FEBRUARY & $-10.03567+0.01647^{\star}$ Ano & 0.1093 & 1.328 \\
MARCH & - & - & - \\
APRIL & $-21.16785+0.2087^{\star}$ Ano & 0.1895 & 1.743 \\
MAY & - & - & - \\
JUNHO & - & - & - \\
JULY & $-16.59154+0.01644^{\star}$ Ano & 0.1074 & 1.328 \\
AUGUST & - & - & - \\
SEPTEMBER & - & - & - \\
OCTOBER & $-38.29537+0.0299^{*}$ Ano & 0.2180 & 1.328 \\
NOVEMBER & $-9.66397+0.01575^{\star}$ Ano & 0.0988 & 1.577 \\
DECEMBER & $-17.47673+0.01993^{\star}$ Ano & 0.1933 & \\
\hline
\end{tabular}


Table 8. Monthly mean values of the volume $(\mathrm{mm})$ of hydric deficiency and hydric surplus in the data analyzed for the region of Machado MG.

\begin{tabular}{ccccc}
\hline & \multicolumn{4}{c}{ PERIOD ANALYZED AT BHC } \\
\cline { 2 - 5 } MONTH & \multicolumn{2}{c}{$1962-2015$} & \multicolumn{2}{c}{$1962-2100$} \\
\cline { 2 - 5 } & DEF & EXC & DEF & EXC \\
\hline JANUARY & 0.0 & 179.7 & 0.0 & 164.2 \\
FEBRUARY & 0.0 & 109.0 & 0.0 & 97.7 \\
MARCH & 0.0 & 84.2 & 0.0 & 86.9 \\
APRIL & 0.0 & 0.0 & -0.7 & 0.0 \\
MAY & 0.0 & 0.0 & 0.0 & 0.0 \\
JUNE & -1.1 & 0.0 & -1.5 & 0.0 \\
JULY & -3.3 & 0.0 & -5.1 & 0.0 \\
AUGUST & -11.6 & 0.0 & -11.7 & 0.0 \\
SEPTEMBER & 0.0 & 0.0 & 0.0 & 0.0 \\
OCTOBER & 0.0 & 0.0 & -52.5 & 0.0 \\
NOVEMBER & 0.0 & 82.3 & 0.0 & 0.0 \\
DECEMBER & 0.0 & 165.4 & 0.0 & 139.6 \\
\hline
\end{tabular}
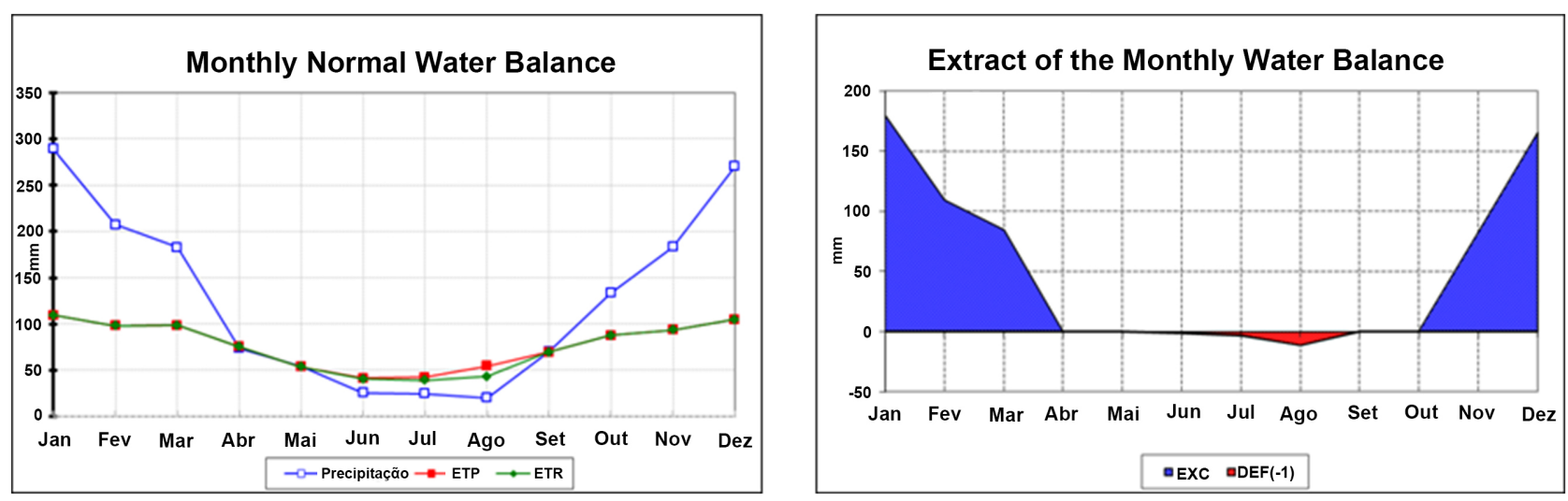

Figure 2. Extract of the Climatologial Hydric Balance in the region of Machado-MG between 1961 and 2015.
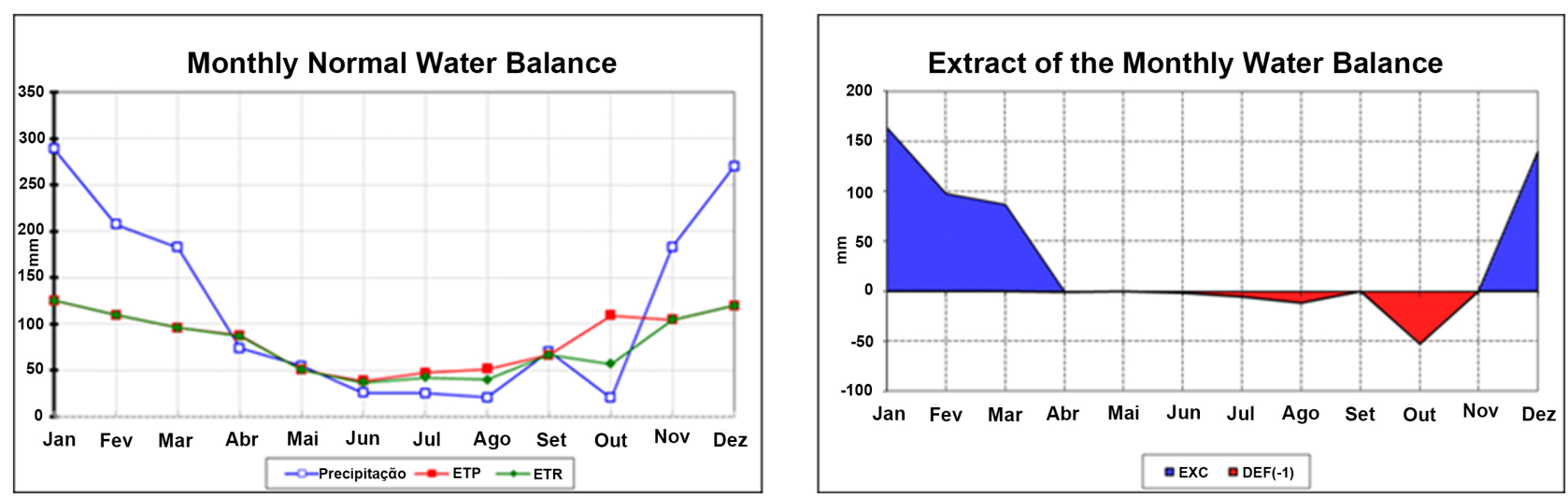

Figure 3. Simulation of the Climatological Hydric Balance Extract in the region of Machado-MG in the period 1961-2015 by the climatic trends. 
The climate classification in the region of Machado would continuous to be a humid mesothermic clime, with little hydric deficiency. However, its category would change from B3 $r$ B'3 a', to B2 r B'4.

\section{Conclusions}

The climate classification of the region of Machado is a humid mesothermic clime, with little hydric deficit $\left(\begin{array}{llll}B_{3} r & B_{3}^{\prime} & a^{\prime}\end{array}\right)$.

The Mann-kendall test and the Pettitt test show an agreement in their results and can be used in order to identify time tendencies. There is tendency of reduction in the average volume of precipitation for October in the average of $1.7 \mathrm{~mm}$ per year.

There is a tendency of average temperature increase for the months of January, February, April, July, October, November and December in the average of $1.6^{\circ} \mathrm{C}$ until the year 2100 .

The significant tendencies in the climate variables studied show that important changes are happening, mainly in the average temperature.

The occurrence of these tendencies over the years may have impacts on agriculture, on the hydrological cycle and, consequently, on the fauna and flora and the population.

\section{Conflicts of Interest}

The authors declare no conflicts of interest regarding the publication of this paper.

\section{References}

[1] Intergovernmental Panel on Climate Change-IPCC (2014) Climate Change 2014: synthesis Report. Contribution of Working Groups I, II and III to the Fifth Assessment Report of the Intergovernmental Panel on Climate, Geneva, $151 \mathrm{p}$.

[2] Marin, F.R., Assad, E.D. and Pilau, F.G. (2008) Clima e ambiente: Introdução à climatologia para a ciências ambientais. Embrapa Informática Agropecuária, Campinas, SP, $127 \mathrm{p}$.

[3] Cecilio, R.A., Silva, K.R., Xavier, A.C. and Pezzopane, J.R.M. (2012) Method for Spatialization of the Climatic Water Balance Elements. Pesquisa Agropecuária Brasileira, 47, 478-488.

[4] Pereira, A.R., Angelocci, L.R. and Sentelhas, P.C. (2002) Agrometeorologia: Fundamentos e aplicações práticas. Ed. Agropecuária, Guaíba, 478 p.

[5] Pena, D.S. (2013) Zoneamento agroclimático do pinhão manso (Jatropha curcas L.) para o estado de Goiás. 2013. 70 f. Dissertação (Mestrado em Agronomia: Solo e Água)_Escola de Agronomia-Universidade Federal de Goiás, Goiânia.

[6] Pereira, A.R., Villanova, N.A. and Sediyama, G.C. (1997) Evapotranspiração. FEALQ, Piracicaba, 183 p.

[7] Black, P. (2007) Revising the Thornthwaite and Mather Water Balance. Journal of the American Water Resources Association, 43, 1604-1605. https://doi.org/10.1111/j.1752-1688.2007.00132.x

[8] Salviano, M.F., Groppo, J.D. and Pellegrino, G.Q. (2015) Trends Analysis of Preci- 
pitation and Temperature Data in Brazil. The Brasilian Journal of Meteorology (RBMET), 31, 64-73.

[9] Queiroz, M.A. (2013) Avaliação de tendências em séries de precipitação diária máxima anual na faixa central do estado de Minas Gerais. 2013. 184 f. Dissertação (Mestre em Saneamento, Meio Ambiente e Recursos Hídricos)-Escola de Engenharia, Universidade Federal de Minas Gerais, Belo Horizonte, 2013.

[10] Minuzzi, R.B. (2010) Tendências na variabilidade climática de Santa Catarina, Brasil. Revista Brasileira de Engenharia Agrícola e Ambiental, 14, 1288-1293. https://doi.org/10.1590/S1415-43662010001200006

[11] Pettitt, A.N. (1979) A Non-Parametric Approach to the Change-Point Problem. Applied Statistics, 28, 126-135. https://doi.org/10.2307/2346729

[12] Rodrigues, G.S., da Silva, A.C., de Oliveira, A.S., Filho, L.R.A.G. and Putti, F.F. (2018) Climate Characterization of the Machado-Mg Region through Geotechnology Techniques and Tools. American Journal of Climate Change, 7, 79-96. https://doi.org/10.4236/ajcc.2018.71007

[13] Thornthwaite, C.W. and Mather, J.R. (1955) The Water Balance. Climatology, 8, 104.

[14] Rolim, G.S., Sentelhas, P.C. and Barbieri, V. (1998) Planilhas no ambiente EXCEL TM para os cálculos de balanços hídricos: Normal, sequencial, de cultura e de produtividade real e potencial. Revista Brasileira de Agrometeorologia, 6, 133-137.

[15] Mann, H.B. (1945) Nonparametric Tests against Trend. Econometrica, 13, 245-259. https://doi.org/10.2307/1907187

[16] Kendall, M.G. (1975) Rank Correlation Methods. Charles Griffin, London, 6 p.

[17] Lopes, J. and Silva, D. (2013) Aplicação do teste de mann-kendall para análise de tendência pluviométrica no estado do Ceará. Revista de Geografia (Recife), 30, 192-208.

[18] Goossens, C. and Berger, A. (1986) Annual and Seasonal Climatic Variations over the Northern Hemisphere and Europe during the Last Century. Annales Geophysicae, 4, 385-400.

[19] Matiello, J.B., Santinato, R., Garcia, A.W., Almeira, S.R. and Fernandes, D.R. (2010) Cultura de café no Brasil: Manual de recomendações. Gráfica Santo Antônio, Varginha, $542 \mathrm{p}$.

[20] Monteiro JEBA (2009) Agrometeorologia dos cultivos: O fator meteorológico na produção agrícola. INMET, Brasília, 530 p.

[21] Cunha, A.R. and Martins, D. (2009) Classificação climática para os municípios de Botucatu e São Manuel, SP. Irriga, Botucatu, 14, 1-11.

[22] Craparo, A.C.W., Vanasten, P.J.A., Läderach, P., Jassogne, L.P.T. and Grab, S.W. (2015) Coffea arabica Yields Decline in Tanzania Due to Climate Change: Global Implications. Agricultural and Forest Meteorology, 207, 1-10. https://doi.org/10.1016/j.agrformet.2015.03.005

[23] Assad, E.D., Pinto, H.S., Zullo Júnior, J., Evangelista, S.R.M., Otavian, A.F., Ávila, M.H., Evangelista, B.A., Marin, F., Macedo Júnior, C., Pellegrino, G., Coltri, P.P. and Coral, G. (2008) A nova geografia da produção agrícola no Brasil. In: Deconto, Ed., Aquecimento global e a nova geografia da produção agrícola no Brasil, Embrapa Informática Agropecuária, Campinas, 82 p.

[24] Ministério da agricultura pecuária e abastecimento (2016) Zoneamento Agrícola de Risco Climático: Instrumento de Gestão de Risco Utilizado pelo Seguro Agrícola do Brasil. http://www.agricultura.gov.br 
[25] Santos, V.O. (2015) Identificação e análise de tendências em séries históricas de precipitação no município de Uberlândia, Minas Gerais. In: XI Encontro Nacional da ANPEGE ENANPEGE, Presidente Prudente. Anais XI Enanpege.

[26] Blain, G.C., Picoli, M.C.A. and Lulu, J. (2009) Análises estatísticas das tendências de elevação nas séries anuais de temperatura mínima do ar no Estado de São Paulo. Bragantia, 68, 807-815. https://doi.org/10.1590/S0006-87052009000300030

[27] Pinê, R.E.L., Pinheiro, R.S.B., Chadouteaud, L.M.L. and Américo, G.H.P. (2014) Mudanças climáticas: $\mathrm{O}$ efeito estufa e a produção agrícola. Revista Científica, ANAP Brasil, 7, 51-61.

[28] Coltri, P.P., Alfonsi, W.M.V., Vanucci, A.L., Gonçalves, R.R.V. and Zullo Júnior, P. (2015) Simulação de temperatura e umidade relativa do café arábica em sistemas arborizados e a pleno sol. In: Simpósio de Pesquisa dos Cafés do Brasil, Embrapa Café, Brasília, 6 p.

[29] Companhia nacional de abastecimento (2015) Acompanhamento da safra brasileira: Café. http://www.conab.gov.br

[30] Ávila, L.F., Mello, C.R., Yanagi, S.N.M. and Neto, O.B.S. (2014) Tendências de temperaturas mínimas e máximas do ar no Estado de Minas Gerais. Pesquisa Agropecuária Brasileira, 49, 247-256. https://doi.org/10.1590/S0100-204X2014000400002 